\title{
Delineating nuclear reprogramming
}

\author{
Jolene Ooi ${ }^{1,2}$, Pentao Liu ${ }^{1 凶}$ \\ ${ }^{1}$ Wellcome Trust Sanger Institute, Hinxton CB10 1SA, United Kingdom \\ ${ }^{2}$ Agency for Science, Technology and Research, Singapore 138632, Singapore \\ $\triangle$ Correspondence: pl2@sanger.ac.uk \\ Received January 1, 2012 Accepted February 4, 2012
}

\begin{abstract}
Nuclear reprogramming is described as a molecular switch, triggered by the conversion of one cell type to another. Several key experiments in the past century have provided insight into the field of nuclear reprogramming. Previously deemed impossible, this research area is now brimming with new findings and developments. In this review, we aim to give a historical perspective on how the notion of nuclear reprogramming was established, describing main experiments that were performed, including (1) somatic cell nuclear transfer, (2) exposure to cell extracts and cell fusion, and (3) transcription factor induced lineage switch. Ultimately, we focus on (4) transcription factor induced pluripotency, as initiated by a landmark discovery in 2006, where the process of converting somatic cells to a pluripotent state was narrowed down to four transcription factors. The conception that somatic cells possess the capacity to revert to an immature status brings about huge clinical implications including personalized therapy, drug screening and disease modeling. Although this technology has potential to revolutionize the medical field, it is still impeded by technical and biological obstacles. This review describes the effervescent changes in this field, addresses bottlenecks hindering its advancement and in conclusion, applies the latest findings to overcome these issues.
\end{abstract}

KEYWORDS nuclear reprogramming, naïve pluripotency

\section{INTRODUCTION}

Nuclear reprogramming is depicted by the transition between distinct cell types introduced by switches in gene patterns. The conception of this phenomenon evolved through the establishment of several experimental milestones and has received heightened interest in the past decades (Fig. 1).

Cellular plasticity is exemplified in nature by a fertilized egg. The notion of its ability to develop into three germ layers and form an entire organism was conceived and described by von Baer, Rathke, and Pander in the 1820s (Pander, 1817; von Baer, 1828). Exploration of these ideas led to the conclusions by Weismann and Roux that development occurred in a unilateral fashion where germ cells are the only cells capable of hereditary potential and somatic cells received permanent genetic modifications, rendering them wedged to perform limited functions. To support his claim, Roux showed that ablation of one cell of the two-cell frog embryo resulted in incomplete development (Roux, 1888). This was quickly confounded by Driesch and Spemann who demonstrated that isolation of single cells from sea urchin (Driesch, 1894) and newt embryos (Spemann, 1928) culminated in the development of complete larvae. However, this did not invalidate the proposal that cells accumulate mutations during differentiation.

The paradigm shift began in 1952 when Briggs and King successfully transplanted a nucleus from a Rana pipiens embryo into an enucleated oocyte to produce adult organisms (Briggs and King, 1952). However, a later study by the pair revealed that endoderm nuclei from an early tail-bud stage resulted in arrest at blastula gastrula and early-neurula stages (King and Briggs, 1955). Surprisingly, when similar experiments were carried out in Xenopus laevis, nuclei from terminally differentiated intestinal epithelial cells were successfully transplanted into irradiated oocytes and developed into fertile male and female frogs (Gurdon, 1962b). This seminal discovery ignited a series of studies and sculpted the views of nuclear reprogramming as we know it today. In this review, we give a historical perspective on the metamorphosis of this field through the description of various approaches to nuclear reprogramming, and subsequently focus on the landmark discovery of transcription factor driven induced 


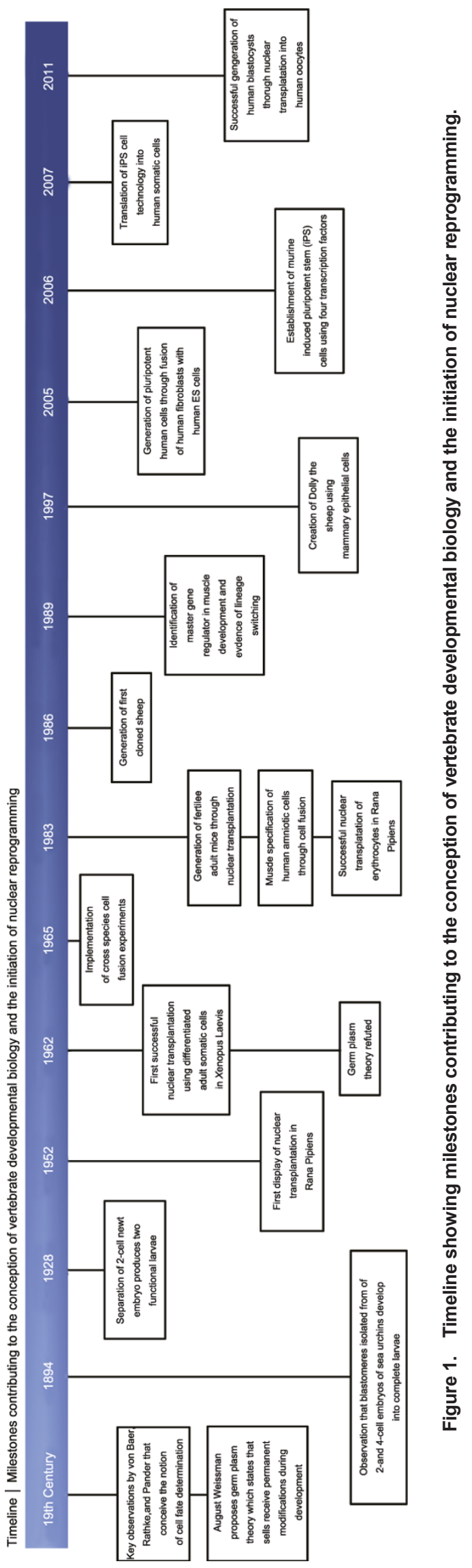


pluripotency. We will highlight the dynamic evolution of this branch of cell manipulation and examine mechanistic insights into this phenomenon. In conclusion, we aim to discuss potential applications of this new technology, coupled to its future direction.

\section{SOMATIC CELL NUCLEAR TRANSFER}

The ability to transplant a nucleus from a differentiated cell into an oocyte to produce viable fertile offspring triggered huge repercussions as it portrayed similar genomic content between oocytes and somatic cells. Fraught with scepticism at the beginning, the experiments were successfully repeated across species. Rising in popularity, this process of transplanting a donor nucleus into an oocyte has now been termed somatic cell nuclear transfer (SCNT).

As described above, the first instance of SCNT was exhibited in Xenopus laevis (Gurdon et al., 1958; Gurdon, 1962a, 1962b). Intestinal epithelium cells of feeding tadpoles which correspond to terminally differentiated endoderm cells gave rise to normal feeding tadpoles at a frequency of $1.5 \%$ when transplanted into unfertilized oocytes. This was noticeably lower than nuclear transfers from the blastula and gastrula endoderm which led to a proportion of $36 \%$ feeding tadpoles. Interestingly, serial transplantations of intestine nuclei which promoted abnormal development after the first transfer could support the formation of normal feeding tadpoles, suggesting that disparities in efficiencies between differentiated and embryonic nuclei were partially explained by non-genetic causes such as technical limitations and incompatible mitotic properties. Collectively, first and serial transplantations, in concert with grafts, generated functional tadpoles at a frequency of 30\% (Gurdon, 1962b; Byrne et al., 2003).

Shortly after came reports of successful transplantations of nuclei from a spectrum of cell origins, such as kidney, lung and skin (Laskey and Gurdon, 1970; Gurdon et al., 1975). Non-dividing erythrocytes from Rana pipiens were demonstrated to produce normal larvae upon serial transplantations (DiBerardino and Hoffner, 1983). Nuclear transfer from myotomes could also effectively produce swimming tadpoles at a frequency of $2 \%$ (Gurdon et al., 1984). Transcription of muscle differentiation markers ceased upon entry into the oocyte and re-activated once gastrulation occurred. Taken together, these studies suggest that the chemical milieu in the oocyte is able to perturb the transcriptional machinery of the donor cell and reverse its differentiation status.

Alternatively, SCNT can be performed using oocytes in their first meiotic prophase (Byrne, 2003). This manipulation results in the swelling of the cell due to a stark increase in mRNA synthesis. DNA replication is reversely synchronized and pauses, contrary to the use of oocytes in the second meiotic metaphase which leads to multiple rounds of cell division and little transcription. Although mechanistically dis- tinct, this reaffirms the intrinsic ability of the oocyte to influence the donor cell nucleus.

Concurrent to the described experiments, other groups ventured away from amphibians. Using one-cell mouse embryos as donor and host, adult mice were generated at a success ratio of $13 \%$ (McGrath and Solter, 1983). In contrast, transplantation of nuclei from tail-tip fibroblasts plunged the reprogramming efficiency to $0.5 \%$. Mirroring this phenomenon in sheep, Willadsen demonstrated the ability to produce cloned lambs by transplanting a nucleus of an 8-cell embryo to an enucleated oocyte (Willadsen, 1986). Mammary gland cell nuclei were also competent to produce adult fertile female sheep, albeit at a low efficiency of $0.2 \%$ (Wilmut et al., 1997).

Several attempts have been made with the use of human oocytes. Injection of donor nuclei into enucleated oocytes gave rise to blastocysts at low frequencies (Stojkovic et al., 2005; Hall et al., 2007; French et al., 2008). Low reprogramming efficiency was alleviated by leaving the nuclei of the oocyte intact (Noggle et al., 2011), leading to the successful development of blastocysts. The inner cell mass was stable in culture and triploid in karyotype, with one set of diploid chromosomes from the somatic nucleus and one set of haploid chromosomes from the oocyte. Competent in producing teratomas consisting of cell types representative of all three germ layers, these cells display similar transcriptional patterns to pluripotent stem cells derived from in vitro fertilized blastocysts.

The findings from SCNT experiments present evidence that somatic cells encompass the capacity to return to pluripotency and can be evaluated in two ways. First, cells which have veered away from pluripotency require strict conditions for reprogramming. Second, the egg naturally contains factors which dominate the performance of the somatic nucleus. Stripping the composition of the egg would allow us to comprehend the intricacies that trigger rapid dedifferentiation. To this end, histones 1 and B4 and the Tet proteins have been illustrated to play roles in the oocyte and male pronucleus, highlighting the importance of epigenetic remodeling interactions during reprogramming (Teranishi et al. 2004; Gao et al., 2004; Becker et al., 2005; Jullien et al., 2010; Maki et al., 2010; Inoue and Zhang, 2011; Wu and Zhang, 2011).

\section{EXPOSURE TO CELL EXTRACTS AND CELL FUSION}

Re-illustrating the innate ability of the chemical milieu within an oocyte to instigate transcriptional alteration, introduction of cytoplasmic contents from Xenopus laevis oocytes and early embryos have been described to elicit the expression of pluripotency markers in human somatic cells (Hansis et al., 2004). This capacity extended till late blastula-stages where extracts were now inhibitory to reprogramming. Human embryonic kidney cells incubated with embryonic carcinoma cell extracts for a mere hour also resulted in transcriptional acti- 
vation and partial demethylation of pluripotency genes within a week (Flasza et al., 2003; Taranger et al., 2005; Freberg et al., 2007).

Corroborating these observations, cell fusions between human lymphocytes and mouse embryonic stem (ES) cells have been competent in triggering the reactivation of Oct4. However, the level of transcriptional induction was $<1 \%$ compared to human ES cells (Pereira et al., 2008). The capacity of cell fusion induced reprogramming has been further exemplified through the combination of male ES cells and female thymocytes. Resulting heterokaryons expressed pluripotency genes and reactivated the silent $\mathrm{X}$ chromosome (Tada et al., 2001). In addition, spontaneous fusion between mouse neural progenitors and mouse ES cells led to the silencing of neural markers (Ying et al., 2002). Replicated in human cells, human ES cells fused to human foreskin fibroblasts generated hybrid pluripotent cells that exhibited the capacity to develop into three germ layers (Cowan et al., 2005). In general, cell fusion experiments displayed trends analagous to SCNT. First, terminally differentiated cells were more demanding to transform. Second, cell fusion leads to rapid reprogramming, where genes are expressed within two days and independent of DNA replication (Pereira et al., 2008; Do and Scholer, 2010). Despite success in generating pluripotent stem cells, reprogramming through cell fusion is inefficient $(\sim 1 \%)$, and creates a bottleneck during the purification of stable hybrids for analysis. Introduction of selection markers in the two starting populations can overcome this problem, but does not alleviate the eventual low population of reprogrammed cells.

Apart from establishing pluripotency, other cell types have also been successfully reprogrammed through cell fusion. Stemming from early experiments, heterokaryons between erythrocytes from a mature hen and Hela cells have been described to swell in size and prompt transcriptional activity in terminally differentiated erythrocytes, reminiscent of the observations in SCNT (Harris, 1965; Harris et al., 1966). Surprisingly, the combination of human amniotic cells and mouse muscle cells triggered the expression of genes specific to muscle cells, albeit the naïve nature of amniotic cells (Blau et al., 1983). This draws attention to inherent factors in somatic cells that safeguard the integrity and lineage of the cell. Besides sharing similarities to SCNT, it is useful to note that cell fusion encompasses unique qualities such as the ability to generate heterokaryons using multiple cell-nuclei. As a result, gene dosage influences the reprogramming efficiencies and the presence of the dominant nuclei in more than two fold will delay transcriptional activation (Pavlath and Blau, 1986).

\section{TRANSCRIPTION FACTOR INDUCED LINEAGE SWITCH}

It is evident from cell fusion experiments that there are specific components within each branch of cell lineage, shielding it from external influences and guarding its designed function. These intrinsic cell specific properties can be harnessed to redirect differentiation signals. Using observations that DNA demethylating agent, 5-azacytidine (AZA) enables efficient reprogramming into muscle lineage (Chiu and Blau, 1985), Weintraub and colleagues identified MyoD as a master regulator of myogenesis, and its ectopic expression forced recipient non-muscle cells to convert into myocytes (Weintraub et al., 1989). Although cells from three germ layers were successfully reprogrammed, starting material originating from the mesoderm was effectively converted, whereas cells from endoderm and ectoderm lineages retained their original gene signatures. This suggests the necessity of additional factors to induce a complete reform of the pre-existing gene expression profile.

To reinforce this notion, transdifferentiation has been described in a natural setting. Glucagon-producing $\alpha$-cells have been reported to transform into pancreatic insulin-producing $\beta$-cells upon a diphtheria toxin insult (Thorel et al., 2010) and pigmented epithelial cells in a newt can regenerate its eye lens when removed (Tsonis and Del Rio-Tsonis, 2004). Time-lapse observation of cultured endothelial sheet colonies revealed their capacity to disengage their tight junctions, round up and begin to display erythroid and monocytic hematopoietic antigens (Eilken et al., 2009).

Intuitively, forced expression of transcription factors that naturally occur during developmental programs can incite lineage switches. As described above, expression of MyoD can redirect non-muscle cells into the muscle lineage (Weintraub et al., 1989). In addition, overexpression of adipocyte-specific nuclear hormone receptor, peroxisome proliferator-activated receptor (PPAR)y2, triggers adipogenesis in fibroblasts (Tontonoz et al., 1994). Although single genetic factors have been described to control cell fate in adipocytes and myocytes, dermal fibroblasts require a combination of Gata4, Mef2c and Tbx5 to be converted into cardiomyocytes (leda et al., 2010). Likewise, ectopic expression of separate sets of transcription factors has successfully triggered transdifferentiation of dermal fibroblasts into neuron-like, blood progenitors, insulin secreting $\beta$-cells and brown adipose cells (Zhou et al., 2008; Kajimura et al., 2009; Szabo et al., 2010; Vierbuchen et al., 2010). Further exploration in the realm of lineage switching has placed emphasis on the importance of spatial, temporal and quantitative control of transcription factor expression in the generation of an array of cell types (Kulessa et al., 1995; Xie et al., 2004; Iwasaki et al., 2006; Laiosa et al., 2006).

Lineage switching mimics the acquisition of pluripotency via SCNT and cell fusion closely. First, cells which have climbed the differentiation ladder face more roadblocks during reprogramming (Chickarmane et al., 2009). Second, lineage switch occurs without the need for cell division. Markers of progenitor cells are often not detected, suggesting that reprogramming may occur in a direct fashion without the 
presence of an undifferentiated intermediate (Thorel et al., 2010). However, this does not exclude the possibility of a transient intermediate state.

\section{TRANSCRIPTION FACTOR INDUCED PLURIPOTENCY}

The ability of transcription factors to impose a lineage switch suggests that the right cocktail of factors would be able to erase all differentiation marks in somatic cells, driving the cell to pluripotency. In 2006, a seminal discovery by Takahashi and Yamanaka illuminated the capacity of four transcription factors, Oct4, c-Myc, Klf4, and Sox2, to transform mouse embryonic fibroblasts into cells that were similar to ES cells and disparate from their original somatic identity. These cells were able to differentiate into three germ layers when injected into immune-compromised mice, portraying its pluripotent potential.

Shortly after, the phenomenon was replicated in human fibroblasts (Takahashi et al., 2007). Concurrently, an independent study reported the generation of human ES-like cells through a discrete set of genes, Oct4, Sox2, Nanog, and Lin28 (Yu et al., 2007). These groundbreaking discoveries indicated that mere four genes can elicit pluripotency, igniting a surge of interest in this sphere of reprogramming (Fig. 2). For the ease of nomenclature, these cells have since been termed as induced pluripotent stem (iPS) cells.

Several refinements have been made to the generation of iPS cells since its inception. This includes the use of surrogate gene delivery tools, encompassing polycistronic lentiviruses, piggyBac mediated transposition and non-integrating approaches such as adenoviruses, Sendai viruses, episomal DNA, repeated transfections of mRNA or plasmid DNA and purified proteins (Okita et al., 2008; Stadtfeld et al., 2008; Carey et al., 2009; Fusaki et al., 2009; Kim et al., 2009a; Sommer et al., 2009; Woltjen et al., 2009; Yu et al., 2009; Yusa et al., 2009; Zhou et al., 2009; Warren et al., 2010). Albeit the low efficiency of producing iPS cells, the employment of non-integrating methods allows the generation of colonies which are completely free of exogenous material. Additional selection markers have also been established to allow the distinction between fully and partially reprogrammed cells (Okita et al., 2007; Maherali et al., 2007; Wang et al., 2011b).

To illustrate the robustness of the protocol, somatic cells originating from the three germ layers have been described to be pliable to reprogramming (Aasen et al., 2008; Aoi et al., 2008; Hanna et al., 2008; Shi et al., 2008). In addition, iPS cells from an array of organisms, including pigs, monkeys and rats, have also been achieved (Liu et al., 2008; Esteban et al., 2009; Liao et al., 2009). Akin to SCNT and cell fusion experiments, terminally differentiated cells have been proven difficult to reprogram (Hanna et al., 2008). Cell types which possess high intrinsic expression of certain factors negotiate the need for the complete set of reprogramming cocktail (Giorgetti et al., 2009; Kim et al., 2009b, 2009c; Tsai et al., 2010). Overall, these studies display the inherent ability of a spectrum of somatic cell types to revert to its pluripotent state. However, this technology is still in its infancy and harbours many unknowns. To address our lack of knowledge on the reprogramming process, it is crucial to begin elucidating the mechanisms behind the induction of pluripotency. There are several approaches which lead us to unravel its molecular circuitry and will be discussed below.

\section{Molecular mechanisms behind the initial set of four reprogramming factors}

Before we endeavour to expand our knowledge of the reprogramming process, it is crucial to understand the roles undertaken by each of the four transcription factors. Naturally present in ES cells, these transcription factors instigate a cascade of molecular events that preserve the functional integrity of the ES cells (Nichols et al., 1998; Avilion et al., 2003; Loh et al., 2006).

Oct4 and Sox2 are principal regulators of the transcriptional network in ES cells and act in concert with Nanog to activate pluripotency-associated elements (Boyer et al., 2005; Masui et al., 2007; Kim et al., 2008). Under tight regulation, deregulation of Oct4 and Sox2 expression levels will lead to differentiation of ES cells (Nichols et al., 1998; Niwa et al., 2000; Tomioka et al., 2002; Chew et al., 2005; Kopp et al., 2008).

Klf4 belongs to the family of Kruppel-like factors which display functional redundancy among family members. Occupying genomic sites similar to the Oct4-Sox2-Nanog cluster (Jiang et al., 2008), the Klf family has been described to act downstream of Oct4, p53 and leukemia inhibitory factor (LIF)/Stat pathways (Rowland et al., 2005; Hall et al., 2009).

c-Myc is a helix-loop-helix/leucine zipper transcription factor that mediates pleiotropic cellular functions including metabolism, cell cycle, splicing, translation, and oncogenic transformation (Klein, 1983; Kim et al., 2008; Sridharan et al., 2009). It has been implicated in the transcriptional elongation in ES cells (Rahl et al., 2010) and shares similar genetic targets with other pluripotency associated transcription factors (Chen et al., 2008; Kim et al., 2008; Dejosez et al., 2008). In ES cells, c-Myc resembles KIf4, acting in the LIF/Stat pathway (Cartwright et al., 2005) and opposing anti-proliferative properties of p21Cip1 (Claassen and Hann, 2000). c-Myc also recruits histone acetylase complexes (Bouchard et al., 2001; Frank et al., 2001), unfolds the chromatin structure in somatic cells and enables under-privileged sites to undergo remodelling.

The four transcription factors participate in the maintenance of the pluripotent state, where Oct4, Sox2 and Klf4 constitute the core apparatus and c-Myc manipulates a wider scope of cellular functions. Although the genomic targets of 
Timeline | Advancements in IPS cell technology since its inception

\section{6}

2007

Inception of iPS cell technology

Discovery of the generation of murine and human iPS cells

\section{8}

2009

2010

2011

2012

Advancements in transcription factor dellvery methods

Adenovirus

Polycistronic lentivirus

Sendal virus

mRNA delivery

Plasmid transfection

Protein transduction

Transposon

Cells from different species and different tissue types are amenable to iPS cell technology

Pig

Monkey

Rat

Stomach cells

Cow

Hepatocytes

Adipose stem cells

Peripheral blood

Optimization of selection marker used during iPS cell generation

Rex1

Oct4

Nanog

Permutation of reprogramming factors in different cell types

Neural stem cells

B lymphocytes

Cord blood

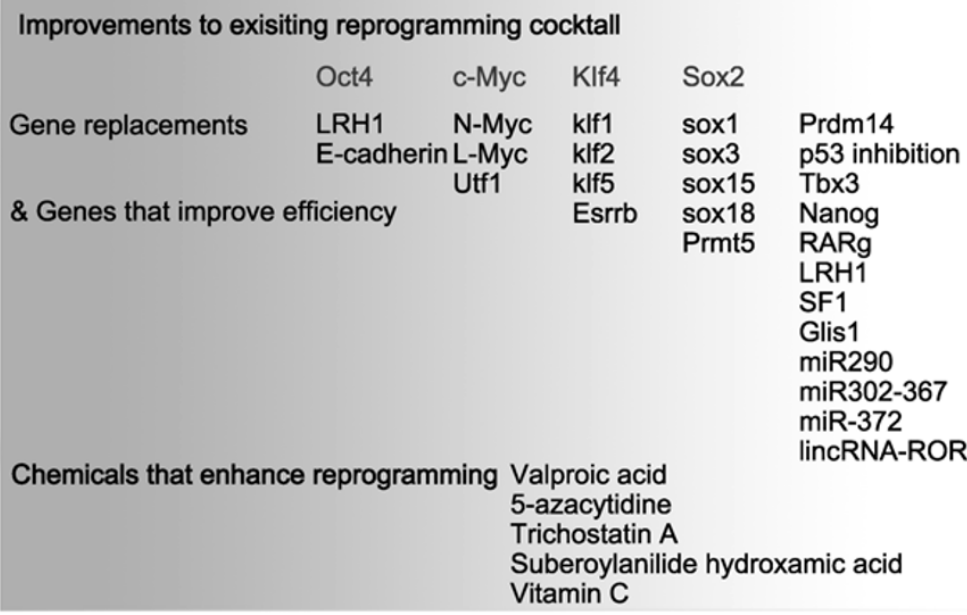

Bringing iPS cell technology closer to the clinic

Disease modeling Drug screening Cell therapy

Amyotrophic lateral sclerosis Long QT syndrome Sickle cell anemia

Hutchinson-Gilford Progeria syndrome Spinal muscular atrophy Alpha 1-antitrypsin deficiency

X-linked adrenoleukodystrophy

Dyskeratosis congenital

Fanconi anemia

Familial hypercholesterolemia

Figure 2. Timeline showing advancements in iPS cell technology since its inception. iPS, induced pluripotent stem. 
each transcription factor act as jigsaw pieces to the pluripotency network puzzle, they do not necessarily reflect the molecular changes coupled to reprogramming in vivo. To acquire a mechanistic view of reprogramming, additional components that participate in the process have been unraveled.

\section{Identification of additional factors and pathways involved in reprogramming}

To peel away layers of complexity behind induced pluripotency, several directed genetic screens have been endeavoured. A handful of genes such as Glis1, Tbx3, and Prmt5 were discovered to improve the original protocol of generating iPS cells (Han et al., 2010; Maekawa et al., 2011; Nagamatsu et al., 2011).

Transcription factors which competently act as substitutes for the prescribed set of reprogramming factors illuminate the role of each gene in the context of reprogramming. Inspection of functional redundancy among family members reveals that relatives of KIf4, Sox2, and c-Myc could successfully operate as substitutes, whereas Oct1 and Oct6 were unable to replace Oct4 (Nakagawa et al., 2008). Subsequent findings denote the ability of Nr5a2, Esrrb and Utf1 to replace Oct4, KIf4, and c-Myc, respectively (Zhao et al., 2008; Feng et al., 2009; Heng et al., 2010). In the absence of Sox2, Prmt5 and Nanog function as substitutes (Ichida et al., 2009; Nagamatsu et al., 2011), with the latter attributed to its synergistic function with Sox2 (Rodda et al., 2005).

Using an unbiased piggyBac-assisted approach, we show that RAR $\gamma$ and NR5A2 (LRH-1) co-operate to augment the transcriptional activity of Oct4 and trigger rapid dedifferentiation (Wang et al., 2011b and unpublished data). Although implication of the retinoic acid pathway in the reprogramming process is surprising, it is not completely unexpected (Ben-Shushan et al., 1995; Barnea and Bergman, 2000). As the dedifferentiation process is distinct to the maintenance of ES cell pluripotency, this study may shed light from a new perspective on the molecular mechanisms behind reprogramming.

Aside from transcription factors, microRNAs have also been addressed (Judson et al., 2009; Liao et al., 2011; Subramanyam et al., 2011). Two independent studies reported that microRNAs alone could reprogram both mouse and human somatic cells (Anokye-Danso et al., 2011; Miyoshi et al., 2011). Extending this discovery, a new class of large intergenic non-coding RNAs (lincRNAs) was portrayed to be involved in pluripotency. Of 10 lincRNAs identified to be differentially expressed in IPS and ES cells, deregulation of lincRNA-RoR in human fibroblasts has been described to affect iPS cell formation (Loewer et al., 2010).

\section{Chemicals that enhance reprogramming}

The route to pluripotency is multi-faceted and complementing chemical screens can illuminate potential approaches to improve the reprogramming process.

Transcription factor induced pluripotency occurs at sub-optimal frequencies of $0.01 \%-0.2 \%$ (reviewed by Hochedlinger and Plath, 2009). Forced re-expression of reprogramming factors in secondary fibroblasts resulted in $20 \%$ of cells displaying early pluripotency markers but a mere $1.2 \%$ of these cells re-activating their endogenous Nanog locus after 16 days (Mikkelsen et al., 2008). Amalgamating this to the knowledge that primitive cells which encompass fewer somatic epigenetic marks are more pliable to dedifferentiation and iPS cells which harbour incomplete erasure of silencing modifications were unable to contribute to the mouse germline (Takahashi and Yamanaka, 2006), it is tempting to speculate that overcoming the epigenetic barrier would enhance reprogramming.

To address this, a DNA methyltransferase inhibitor, AZA, was described to propel partially reprogrammed cells into pluripotency and improved the efficiency of producing iPS cell colonies by 4-fold (Huangfu et al., 2008a; Mikkelsen et al., 2008). Given that c-Myc regulates histone deacetylation and greatly improves reprogramming efficiencies, histone deacetylase inhibitors, such as valproic acid, trichostatin $A$, and suberoylanilide hydroxamic acid, have been proven to be efficacious in increasing the kinetics and efficiencies of generating iPS cells (Huangfu et al., 2008a, 2008b). Moreover, valproic acid ablates the need for C-Myc and Klf4, producing ES-like cells solely in the presence of Oct4 and Sox2.

As reprogramming leads to the accumulation of reactive oxygen species, antioxidant vitamin $\mathrm{C}$ was described to increase the efficiency of generating iPS cells (Esteban et al., 2010). This is triggered by vitamin C-dependent H3K36me2/3 demethylation and the repression of p53/p21 and Ink4/Arf loci (Wang et al., 2011a).

Besides the addition of chemicals, altering environmental conditions during reprogramming can also benefit the generation of iPS cells. In a natural setting, development of embryos occurs in physiologically hypoxic conditions. Recapitulating low oxygen concentrations during reprogramming experiments increases the efficiency of obtaining iPS cells (Yoshida et al., 2009). Furthermore, resultant female human iPS cells exhibit two activated copies of $X$ chromosomes, indicating the attainment of ground state pluripotency (Lengner et al., 2010). Possible explanations behind this phenomenon include decreased accumulation of chromosomal abnormalities (Forsyth et al., 2006) and protection against spontaneous differentiation (Ezashi et al., 2005; Prasad et al., 2009).

\section{Cellular processes associated with reprogramming}

Although the search for genes and chemicals that enhance the creation of iPS cells has yielded a considerable amount of 
information, other avenues of studying the dedifferentiation process have also provided us with much insight. Two complementary approaches were used to determine the importance of mesenchymal-to-epithelial transition (MET) during the reprogramming process ( $\mathrm{Li}$ et al., 2010; Samavarchi-Tehrani et al., 2010). Molecular dissection of the process identified bone morphogenetic proteins (BMP) as a key mediator, leading to a later discovery that BMP can replace KIf4 in the reprogramming process, and its expression with Oct4 alone is sufficient to generate iPS cells (Chen et al., 2011). These findings were corroborated by two independent studies describing the essential roles of E-cadherin (Redmer et al., 2011) and the TGF $\beta$ pathway (Ichida et al., 2009) in driving partially reprogrammed cells to pluripotency.

Secondary cells isolated from chimeras act as a homogenous platform to study the mechanics behind induced pluripotency. Silencing p53 or p21, or over-expressing Lin28 in secondary B-cells improved reprogramming efficiencies in a cell division dependent manner (Hanna et al., 2009). This validated an initial finding that silencing p53 in primary fibroblasts improved reprogramming conditions (Zhao et al., 2008). In addition five studies also illustrated the role of DNA damage response and immortalization in reprogramming (Hong et al., 2009; Kawamura et al., 2009; Li et al., 2009a; Marión et al., 2009; Utikal et al., 2009).

The importance of cell division in generating iPS cells is disparate to the mechanics behind SCNT and cell fusion, insinuating that the current recipe of transcription factors is unable to replicate natural reprogramming events. Interestingly, delivery of Nanog into secondary B-cells increased the number of reprogrammed colonies, independent of cell division (Hanna et al., 2009). Nanog is known to play essential roles in reprogramming and cell fusion (Silva et al., 2006; Chambers et al., 2007; Yu et al., 2007; Silva et al., 2009), hence it is possible that it functions in a discrete role, providing a new dimension to the process.

\section{Functional applications of iPS cells}

The discovery of iPS cells was accompanied with the promise of personalized cell therapy and the creation of avenues for drug screening and disease modeling. Since the advent of this technology, several studies have been conducted to serve as proof-of-principle for future applications.

Foremost, it is important to demonstrate that biopsies retrieved from patients can be competently reprogrammed and recapitulate the disease when differentiated. To this end, dermal fibroblasts, primary hepatocytes, blood, and keratinocytes have been shown to be effectively reprogrammed (Aasen et al., 2008; Dimos et al., 2008; Giorgetti et al., 2009; Loh et al., 2009; Liu et al., 2010). Extending these findings, the first notion of disease modeling was established through the generation of iPS cells from patients with a series of hu- man disorders (Park et al., 2008). This was further exemplified in amyotrophic lateral sclerosis where reprogrammed cells could effectively differentiate into motor neurons (Dimos et al., 2008), displaying its capacity to model the disease. A plethora of diseases have since been recapitulated, including familial hypercholesterolemia, X-linked adrenoleukodystrophy, dyskeratosis congenital, Hutchinson-Gilford Progeria syndrome, and Down's Syndrome (Rashid et al., 2010; Agarwal et al., 2010; Jang et al., 2011; Zhang et al., 2011; Shi et al., 2012).

iPS cells also act as a suitable platform to perform drug screening tests, as portrayed in Long QT syndrome type I (Moretti et al., 2010; Itzhaki et al., 2011). Cardiomyocytes differentiated from patient derived cells demonstrated the classical electrocardiographic aberration of a long QT interval and were susceptible to catecholamine-induced tachyarrhythmia, whereas the addition of $\beta$-adrenergic receptor blockers could rescue this phenotypic abnormality. Drug screening abilities of iPS cells have also been illustrated in the contexts of spinal muscular atrophy and familial dysautonomia ((Ebert et al., 2009; Lee et al., 2009).

The inception of iPS cell technology highlights the potential of cell therapy and has been addressed in an autologous mouse model displaying sickle cell anemia (Hanna et al., 2007). This was followed by the notion of human iPS cell therapy in the treatment of spinal cord injuries and Fanconi anemia (FA) (Raya et al., 2009; Nori et al., 2011). More recently, targeted gene correction in human iPS cells was demonstrated through the application of piggyBac transposons and zinc-finger nucleases (Yusa et al., 2011), surmounting potential silencing modifications of rescue cassettes delivered by viruses (Raya et al., 2009).

Although the use of iPS cells in the clinic is regarded attractively, there are several anomalies which have to be addressed. Cells derived from patients suffering from FA and Fragile $X(F X)$ syndrome are not easily amenable (Raya et al., 2009; Urbach et al., 2010), where additional genetic modifications are necessary to produce FA iPS cells, and FX iPS cells do not recapitulate the disease phenotype. These bottlenecks impede disease modelling and amendments to the existing protocol have to be taken into consideration.

\section{Current pitfalls in reprogramming}

In addition to technical difficulties, there are several concerns about the authenticity of iPS cells, in relation to ES cells. Using available techniques, rigorous comparisons have been performed between ES cells and iPS cells. Comprehensive studies of phosphoproteomic and transcriptomic components revealed minute differences that were statistically disregarded (Phanstiel et al., 2011). However, epigenomic analysis at high resolution revealed subtle differences between human iPS cells and ES cells (Lister et al., 2011). Differentially methylated regions (DMRs) associated with CG islands 
and genes were observed and these differences can be catalogued to represent persistent methylation patterns from the parental cell and de novo signatures specific to iPSCs. Additionally, aberrant silencing of the imprinted Dlk1-Dio3 gene cluster on chromosome $12 \mathrm{qF} 1$ in mice has also been correlated to poor chimera contributions and low germline competence (Stadtfeld et al., 2010). Overall, these studies point out that there are epigenetic discrepancies between iPS cells and ES cells.

Given these differences, it is understandable that functional disparities, such as epigenetic memory, exist between iPS cells and ES cells (Kim et al., 2010; Polo et al., 2010; Ohi et al., 2011). Blood-derived iPS cells displayed higher competence in differentiating into blood cells than neural progenitor-derived iPS cells, but at similar competence to nuclear-transfer-derived ESCs (Kim et al., 2010). However, differentiation of non-blood cells into blood prior to a second round of reprogramming markedly increases their blood forming capability, reiterating the notion of epigenetic footprints corresponding to the somatic state prior to reprogramming.

Another concern which has risen recently is the immunogenicity of autologous iPS cells. Injection of allogenic ES cells or highly autologous iPS cells into immune competent C57BL/6 mice elicited an immune response (Zhao et al., 2011). In contrast, autologous C57BL/6 ES cells were successfully implanted and generated teratomas efficiently. Reasons behind this phenomenon remain unclear but it is crucial that these observations are reproduced in independent studies before they can be generalized.

Given the differences between iPS cells and ES cells, it is pivotal to refine our methods in reprogramming. Prolonged maintenance of iPS cells has been suggested to erase sustained epigenetic marks (Polo et al., 2010); however continuous in vitro culture of these cells may incur genomic aberrations, as suggested by several independent groups (Gore et al., 2011; Hussein et al., 2011; Lister et al., 2011). Alternatively, the stoichiometry of the reprogramming factors has been suggested to affect the epigenetic status of the reprogrammed cells, strongly influencing their pluripotency (Carey et al., 2011).

\section{Ground state or naïve pluripotent stem cells}

To date, several stages of pluripotency have been recapitulated on a Petri dish (Fig. 3). ES cells derived from the inner cell mass of the mouse blastocyst (Evans and Kaufman, 1981) depict a naïve state of pluripotency and display germline competence when reintroduced into the mouse blastocyst. In culture, ES cells require LIF and BMP for maintenance. The addition of GSK3 $\beta$ and MEK inhibitors (2i) shields these pluripotent cells from differentiation-inducing stimuli and select for a homogenous population of primitive cells, designated as ground state pluripotency (Ying et al., 2008).
Introduction of $2 \mathrm{i}$ to early mouse embryos does not impede blastocyst formation and results in high uniform expression of Nanog within the inner cell mass (Nichols et al., 2009). This proposes the presence of ground state pluripotency within the early mouse embryo, as denoted by the Nanog-expressing cells.

Epiblast stem cells (EpiSCs) were established from late epiblast layers and represent a primed pluripotent state (Brons et al., 2007; Tesar et al., 2007). In contrast to ES cells, EpiSCs are maintained in fibroblast growth factor (FGF) and Activin. Grown as flat compact colonies, they are morphologically distinct from domed mouse ES cell colonies, and can rarely generate chimeras when injected into immune-compromised mice. EpiSCs can be converted into ES cells through the addition of LIF or the ectopic expression of KIf2, KIf4, or Nr5a2 and the addition of 2i and LIF (Bao et al., 2009; Guo et al., 2009; Guo and Smith, 2010).

Human ES cells have been successfully isolated from human blastocysts (Thomson et al., 1998). Unlike mouse ES cells, the human ES cells require FGF and/or Activin for sustenance and the presence of LIF is insufficient to maintain them in an undifferentiated state. These pieces of evidence suggest that human ES cells resemble EpiSCs to a higher degree than their mouse counterparts (Tesar et al., 2007), indicating the existence of an unexplored naïve human pluripotent state. This notion is strengthened by the recent finding that Nanog-expressing cells within the human embryo do not respond to the inhibition of FGF and extracellular signal-regulated kinases (ERK) signals (Kuijk et al., 2012; Roode et al., 2012).

Given that conventional human iPS cells display a close relationship to human ES cells, the establishment of a stable primitive state may overcome the bottlenecks experienced by traditional human iPS cells. To address this, several studies have attempted to isolate immature human iPS cells. These strategies revolve around the ectopic constitutive expression of expanded sets of transcription factors and the addition of a spectrum of chemicals (Li et al., 2009b; Buecker et al., 2010; Hanna et al., 2010). Resultant cells resemble ES cells morphologically and display X-reactivation in female cells.

More recently, we have demonstrated that a cocktail of $\mathrm{RAR} \gamma, \mathrm{Nr} 5 \mathrm{a} 2$ and the conventional set of reprogramming factors, can create naïve human pluripotent cells (Wang et al., 2011b). Coined as Sanger human iPS (SH-iPS) cells, these cells are stable over 50 passages, display dependency on the JAK/Stat pathway and generate teratomas when injected into immune-compromised mice. Using female cells as a starting material, SH-iPS cells exhibit two active X-chromosomes. Interestingly, exposure to FGF and Activin triggered their conversion to human ES-like cells, resembling the conversion of mouse ES cells to EpiSCs in similar conditions. This affirms the existence of a stable naïve state in human induced pluripotency and its competence to be maintained in culture. 
Comparison between different pluripotent states in the mouse and human

$$
\text { Naive pluripotent state } \quad \text { Primed pluripotent state Non-pluripotent state }
$$

Mouse

$$
\text { Embryonic stem cell }
$$

Genes that can promote

conversion between states

\begin{tabular}{|c|c|}
\hline Culture conditions & Dependent on LIF, serum and BMP4 \\
\hline Morphology & $\begin{array}{l}\text { Three dimensional, } \\
\text { round and compact }\end{array}$ \\
\hline $\begin{array}{l}\text { Differentiation } \\
\text { potential }\end{array}$ & $\begin{array}{l}\text { Teratoma formation } \\
\text { chimera generation, } \\
\text { germline contribution, } \\
\text { tetraploid complentation }\end{array}$ \\
\hline $\mathrm{X}$-inactivation status & Active \\
\hline Cell surface marker & SSEA1 \\
\hline
\end{tabular}

Induced pluripotent stem cell

Dependent on FGF and Activin
Two dimensional and flat
Teratoma formation
Inactive
SSEA3/4

Variable

Variable

None

Inactive

Human

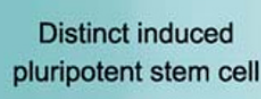

pluripotent stem cell

\section{Genes that can promote}

conversion between states
Variable

\section{and}

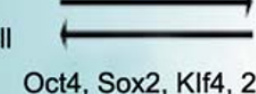

Embryonic stem cell

Conventional induced

pluripotent stem cell

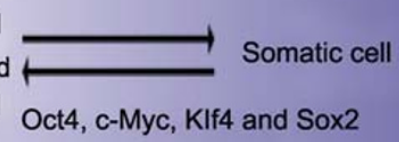

and Forskolin

Oct4 and KIf4

KIf2 and KIf4

Oct4, C-Myc, KIf4, Sox2, RARg and LRH1

Oct4, Sox2, Nanog, Lin28 and the addition of inhibitors

Oct4, Sox2, Nanog, c-Myc and Klf4 
The discovery of this primitive state in human cells has immense implications. FGF-dependent human ES cells and iPS cells are technically difficult to maintain in culture. Susceptible to harsh dissociation, these cells are unable to survive devoid of cell-cell interation and exhibit genetic instability (Brimble et al., 2004; Buzzard et al., 2004; Lefort et al., 2008; Spits et al., 2008; Mayshar et al., 2010; Amps et al., 2011). In contrast, naïve human iPS cells do not display these properties and can be manipulated with ease. Resistant to tougher handling techniques, these cells are possibly more amenable to homologous recombination, creating a huge potential for genetic modification and correction. Naïve human iPS cells are also genetically and epigenetically stable, overcoming hurdles for its prospective use in the clinic. Despite these advantages, current protocols to derive naïve human iPS cells are not optimal. Further development is necessary to improve reprogramming efficiencies to levels comparable to or better than the generation of conventional FGF-dependent iPS cells. Nevertheless, since the inception of transcription factor induced pluripotency, the wealth of knowledge has amassed exponentially and continuation on this journey will inch us towards the translation of this technology to the bedside.

\section{ABBREVIATIONS}

EC cells, embryonic carcinoma cells; ES cells, embryonic stem cells; EpiSCs, Epiblast stem cells; ERK, extracellular signal-regulated kinases; FGF, fibroblast growth factor; iPS cells, induced pluripotent stem cells; LIF, leukemia inhibitory factor; SCNT, somatic cell nuclear transfer; $2 \mathrm{i}$, two inhibitors

\section{REFERENCES}

Aasen, T., Raya, A., Barrero, M.J., Garreta, E., Consiglio, A., Gonzalez, F., Vassena, R., Bilić, J., Pekarik, V., Tiscornia, G., et al. (2008). Efficient and rapid generation of induced pluripotent stem cells from human keratinocytes. Nat Biotechnol 26, 1276-1284.

Agarwal, S., Loh, Y.H., McLoughlin, E.M., Huang, J., Park, I.H., Miller, J.D., Huo, H., Okuka, M., Dos Reis, R.M., Loewer, S., et al. (2010). Telomere elongation in induced pluripotent stem cells from dyskeratosis congenita patients. Nature 464, 292-296.

Amps, K., Andrews, P.W., Anyfantis, G., Armstrong, L., Avery, S., Baharvand, H., Baker, J., Baker, D., Munoz, M.B., Beil, S., et al., and the International Stem Cell Initiative. (2011). Screening ethnically diverse human embryonic stem cells identifies a chromosome 20 minimal amplicon conferring growth advantage. Nat Biotechnol 29, 1132-1144.

Anokye-Danso, F., Trivedi, C.M., Juhr, D., Gupta, M., Cui, Z., Tian, Y., Zhang, Y., Yang, W., Gruber, P.J., Epstein, J.A., et al. (2011). Highly efficient miRNA-mediated reprogramming of mouse and human somatic cells to pluripotency. Cell Stem Cell 8, 376-388.

Aoi, T., Yae, K., Nakagawa, M., Ichisaka, T., Okita, K., Takahashi, K., Chiba, T., and Yamanaka, S. (2008). Generation of pluripotent stem cells from adult mouse liver and stomach cells. Science 321,
699-702.

Avilion, A.A., Nicolis, S.K., Pevny, L.H., Perez, L., Vivian, N., and Lovell-Badge, R. (2003). Multipotent cell lineages in early mouse development depend on SOX2 function. Genes Dev 17, 126-140.

Bao, S., Tang, F., Li, X., Hayashi, K., Gillich, A., Lao, K., and Surani, M.A. (2009). Epigenetic reversion of post-implantation epiblast to pluripotent embryonic stem cells. Nature 461, 1292-1295.

Barnea, E., and Bergman, Y. (2000). Synergy of SF1 and RAR in activation of Oct-3/4 promoter. J Biol Chem 275, 6608-6619.

Becker, M., Becker, A., Miyara, F., Han, Z., Kihara, M., Brown, D.T., Hager, G.L., Latham, K., Adashi, E.Y., and Misteli, T. (2005). Differential in vivo binding dynamics of somatic and oocyte-specific linker histones in oocytes and during ES cell nuclear transfer. Mol Biol Cell 16, 3887-3895.

Ben-Shushan, E., Sharir, H., Pikarsky, E., and Bergman, Y. (1995). A dynamic balance between ARP-1/COUP-TFII, EAR-3/COUP-TFI, and retinoic acid receptor:retinoid $X$ receptor heterodimers regulates Oct-3/4 expression in embryonal carcinoma cells. Mol Cell Biol 15, 1034-1048.

Blau, H.M., Chiu, C.P., and Webster, C. (1983). Cytoplasmic activation of human nuclear genes in stable heterocaryons. Cell 32 , 1171-1180.

Bouchard, C., Dittrich, O., Kiermaier, A., Dohmann, K., Menkel, A., Eilers, M., and Lüscher, B. (2001). Regulation of cyclin D2 gene expression by the Myc/Max/Mad network: Myc-dependent TRRAP recruitment and histone acetylation at the cyclin D2 promoter. Genes Dev 15, 2042-2047.

Boyer, L.A., Lee, T.I., Cole, M.F., Johnstone, S.E., Levine, S.S., Zucker, J.P., Guenther, M.G., Kumar, R.M., Murray, H.L., Jenner, R.G., et al. (2005). Core transcriptional regulatory circuitry in human embryonic stem cells. Cell 122, 947-956.

Briggs, R., and King, T.J. (1952). Transplantation of Living Nuclei From Blastula Cells into Enucleated Frogs' Eggs. Proc Natl Acad Sci U S A 38, 455-463.

Brimble, S.N., Zeng, X., Weiler, D.A., Luo, Y., Liu, Y., Lyons, I.G., Freed, W.J., Robins, A.J., Rao, M.S., and Schulz, T.C. (2004). Karyotypic stability, genotyping, differentiation, feeder-free maintenance, and gene expression sampling in three human embryonic stem cell lines derived prior to August 9, 2001. Stem Cells Devel 13, 585-597.

Brons, I.G., Smithers, L.E., Trotter, M.W., Rugg-Gunn, P., Sun, B., Chuva de Sousa Lopes, S.M., Howlett, S.K., Clarkson, A., Ahrlund-Richter, L., Pedersen, R.A., et al. (2007). Derivation of pluripotent epiblast stem cells from mammalian embryos. Nature 448 , 191-195.

Buecker, C., Chen, H.H., Polo, J.M., Daheron, L., Bu, L., Barakat, T.S., Okwieka, P., Porter, A., Gribnau, J., Hochedlinger, K., et al. (2010). A murine ESC-like state facilitates transgenesis and homologous recombination in human pluripotent stem cells. Cell Stem Cell 6, 535-546.

Buzzard, J.J., Gough, N.M., Crook, J.M., and Colman, A. (2004). Karyotype of human ES cells during extended culture. Nat Biotechnol 22, 381-382, author reply 382.

Byrne, J.A., Simonsson, S., Western, P.S., and Gurdon, J.B. (2003). Nuclei of adult mammalian somatic cells are directly reprogrammed to oct- 4 stem cell gene expression by amphibian oocytes. Curr Biol 13, 1206-1213. 
Carey, B.W., Markoulaki, S., Hanna, J., Saha, K., Gao, Q., Mitalipova, M., and Jaenisch, R. (2009). Reprogramming of murine and human somatic cells using a single polycistronic vector. Proc Natl Acad Sci U S A 106, 157-162.

Carey, B.W., Markoulaki, S., Hanna, J.H., Faddah, D.A., Buganim, Y., Kim, J., Ganz, K., Steine, E.J., Cassady, J.P., Creyghton, M.P., et al. (2011). Reprogramming factor stoichiometry influences the epigenetic state and biological properties of induced pluripotent stem cells. Cell Stem Cell 9, 588-598.

Cartwright, P., McLean, C., Sheppard, A., Rivett, D., Jones, K., and Dalton, S. (2005). LIF/STAT3 controls ES cell self-renewal and pluripotency by a Myc-dependent mechanism. Development 132, 885-896.

Chambers, I., Silva, J., Colby, D., Nichols, J., Nijmeijer, B., Robertson, M., Vrana, J., Jones, K., Grotewold, L., and Smith, A. (2007). Nanog safeguards pluripotency and mediates germline development. Nature 450, 1230-1234.

Chen, J., Liu, J., Yang, J., Chen, Y., Chen, J., Ni, S., Song, H., Zeng, L., Ding, K., and Pei, D. (2011). BMPs functionally replace Klf4 and support efficient reprogramming of mouse fibroblasts by Oct4 alone. Cell Res 21, 205-212.

Chen, X., Xu, H., Yuan, P., Fang, F., Huss, M., Vega, V.B., Wong, E., Orlov, Y.L., Zhang, W., Jiang, J., et al. (2008). Integration of external signaling pathways with the core transcriptional network in embryonic stem cells. Cell 133, 1106-1117.

Chew, J.L., Loh, Y.H., Zhang, W., Chen, X., Tam, W.L., Yeap, L.S., Li, P., Ang, Y.S., Lim, B., Robson, P., et al. (2005). Reciprocal transcriptional regulation of Pou5f1 and Sox2 via the Oct4/Sox2 complex in embryonic stem cells. Mol Cell Biol 25, 6031-6046.

Chickarmane, V., Enver, T., and Peterson, C. (2009). Computational modeling of the hematopoietic erythroid-myeloid switch reveals insights into cooperativity, priming, and irreversibility. PLoS Comput Biol 5, e1000268.

Chiu, C.P., and Blau, H.M. (1985). 5-Azacytidine permits gene activation in a previously noninducible cell type. Cell 40, 417-424.

Claassen, G.F., and Hann, S.R. (2000). A role for transcriptional repression of $\mathrm{p} 21 \mathrm{CIP} 1$ by $\mathrm{c}-\mathrm{Myc}$ in overcoming transforming growth factor beta -induced cell-cycle arrest. Proc Natl Acad Sci U S A 97, 9498-9503.

Cowan, C.A., Atienza, J., Melton, D.A., and Eggan, K. (2005). Nuclear reprogramming of somatic cells after fusion with human embryonic stem cells. Science 309, 1369-1373.

Dejosez, M., Krumenacker, J.S., Zitur, L.J., Passeri, M., Chu, L.F., Songyang, Z., Thomson, J.A., and Zwaka, T.P. (2008). Ronin is essential for embryogenesis and the pluripotency of mouse embryonic stem cells. Cell 133, 1162-1174.

DiBerardino, M.A., and Hoffner, N.J. (1983). Gene reactivation in erythrocytes: nuclear transplantation in oocytes and eggs of Rana. Science 219, 862-864.

Dimos, J.T., Rodolfa, K.T., Niakan, K.K., Weisenthal, L.M., Mitsumoto, H., Chung, W., Croft, G.F., Saphier, G., Leibel, R., Goland, R., et al. (2008). Induced pluripotent stem cells generated from patients with ALS can be differentiated into motor neurons. Science 321 , 1218-1221.

Do, J.T., and Scholer, H.R. (2010). Cell fusion-induced reprogramming. Meth Mol Biol 636, 179-190.

Driesch, H. (1894). Analytische theorie der organischen entwicklung
(Leipzig, W. Engelmann).

Ebert, A.D., Yu, J., Rose, F.F. Jr, Mattis, V.B., Lorson, C.L., Thomson, J.A., and Svendsen, C.N. (2009). Induced pluripotent stem cells from a spinal muscular atrophy patient. Nature 457, 277-280.

Eilken, H.M., Nishikawa, S., and Schroeder, T. (2009). Continuous single-cell imaging of blood generation from haemogenic endothelium. Nature 457, 896-900.

Esteban, M.A., Wang, T., Qin, B., Yang, J., Qin, D., Cai, J., Li, W., Weng, Z., Chen, J., Ni, S., et al. (2010). Vitamin C enhances the generation of mouse and human induced pluripotent stem cells. Cell Stem Cell 6, 71-79.

Esteban, M.A., Xu, J., Yang, J., Peng, M., Qin, D., Li, W., Jiang, Z., Chen, J., Deng, K., Zhong, M., et al. (2009). Generation of induced pluripotent stem cell lines from Tibetan miniature pig. J Biol Chem 284, 17634-17640.

Evans, M.J., and Kaufman, M.H. (1981). Establishment in culture of pluripotential cells from mouse embryos. Nature 292, 154-156.

Ezashi, T., Das, P., and Roberts, R.M. (2005). Low O2 tensions and the prevention of differentiation of hES cells. Proc Natl Acad Sci U S A 102, 4783-4788.

Feng, B., Jiang, J., Kraus, P., Ng, J.H., Heng, J.C., Chan, Y.S., Yaw, L.P., Zhang, W., Loh, Y.H., Han, J., et al. (2009). Reprogramming of fibroblasts into induced pluripotent stem cells with orphan nuclear receptor Esrrb. Nat Cell Biol 11, 197-203.

Flasza, M., Shering, A.F., Smith, K., Andrews, P.W., Talley, P., and Johnson, P.A. (2003). Reprogramming in inter-species embryonal carcinoma-somatic cell hybrids induces expression of pluripotency and differentiation markers. Cloning Stem Cells 5, 339-354.

Forsyth, N.R., Musio, A., Vezzoni, P., Simpson, A.H., Noble, B.S., and McWhir, J. (2006). Physiologic oxygen enhances human embryonic stem cell clonal recovery and reduces chromosomal abnormalities. Cloning Stem Cells 8, 16-23.

Frank, S.R., Schroeder, M., Fernandez, P., Taubert, S., and Amati, B. (2001). Binding of c-Myc to chromatin mediates mitogen-induced acetylation of histone $\mathrm{H} 4$ and gene activation. Genes Dev 15, 2069-2082.

Freberg, C.T., Dahl, J.A., Timoskainen, S., and Collas, P. (2007). Epigenetic reprogramming of OCT4 and NANOG regulatory regions by embryonal carcinoma cell extract. Mol Biol Cell 18, 1543-1553.

French, A.J., Adams, C.A., Anderson, L.S., Kitchen, J.R., Hughes, M.R., and Wood, S.H. (2008). Development of human cloned blastocysts following somatic cell nuclear transfer with adult fibroblasts. Stem Cells 26, 485-493.

Fusaki, N., Ban, H., Nishiyama, A., Saeki, K., and Hasegawa, M. (2009). Efficient induction of transgene-free human pluripotent stem cells using a vector based on Sendai virus, an RNA virus that does not integrate into the host genome. Proc Jpn Acad Ser B Phys Biol Sci 85, 348-362.

Gao, S., Chung, Y.G., Parseghian, M.H., King, G.J., Adashi, E.Y., and Latham, K.E. (2004). Rapid $\mathrm{H} 1$ linker histone transitions following fertilization or somatic cell nuclear transfer: evidence for a uniform developmental program in mice. Dev Biol 266, 62-75.

Giorgetti, A., Montserrat, N., Aasen, T., Gonzalez, F., Rodríguez-Pizà, I., Vassena, R., Raya, A., Boué, S., Barrero, M.J., Corbella, B.A., et al. (2009). Generation of induced pluripotent stem cells from human cord blood using OCT4 and SOX2. Cell Stem Cell 5, 
353-357.

Gore, A., Li, Z., Fung, H.L., Young, J.E., Agarwal, S., Antosiewicz-Bourget, J., Canto, I., Giorgetti, A., Israel, M.A., Kiskinis, E., et al. (2011). Somatic coding mutations in human induced pluripotent stem cells. Nature 471, 63-67.

Guo, G., and Smith, A. (2010). A genome-wide screen in EpiSCs identifies $\mathrm{Nr} 5 \mathrm{a}$ nuclear receptors as potent inducers of ground state pluripotency. Development 137, 3185-3192.

Guo, G., Yang, J., Nichols, J., Hall, J.S., Eyres, I., Mansfield, W., and Smith, A. (2009). Klf4 reverts developmentally programmed restriction of ground state pluripotency. Development 136, 1063-1069.

Gurdon, J.B. (1962a). Adult frogs derived from the nuclei of single somatic cells. Dev Biol 4, 256-273.

Gurdon, J.B. (1962b). The developmental capacity of nuclei taken from intestinal epithelium cells of feeding tadpoles. J Embryol Exp Morphol 10, 622-640.

Gurdon, J.B., Brennan, S., Fairman, S., and Mohun, T.J. (1984). Transcription of muscle-specific actin genes in early Xenopus development: nuclear transplantation and cell dissociation. Cell 38 691-700.

Gurdon, J.B., Elsdale, T.R., and Fischberg, M. (1958). Sexually mature individuals of Xenopus laevis from the transplantation of single somatic nuclei. Nature 182, 64-65.

Gurdon, J.B., Laskey, R.A., and Reeves, O.R. (1975). The developmental capacity of nuclei transplanted from keratinized skin cells of adult frogs. J Embryol Exp Morphol 34, 93-112.

Hall, J., Guo, G., Wray, J., Eyres, I., Nichols, J., Grotewold, L., Morfopoulou, S., Humphreys, P., Mansfield, W., Walker, R., et al. (2009). Oct4 and LIF/Stat3 additively induce Krüppel factors to sustain embryonic stem cell self-renewal. Cell Stem Cell 5, 597-609.

Hall, V.J., Compton, D., Stojkovic, P., Nesbitt, M., Herbert, M., Murdoch, A., and Stojkovic, M. (2007). Developmental competence of human in vitro aged oocytes as host cells for nuclear transfer. Hum Reprod 22, 52-62.

Han, J., Yuan, P., Yang, H., Zhang, J., Soh, B.S., Li, P., Lim, S.L., Cao, S., Tay, J., Orlov, Y.L., et al. (2010). Tbx3 improves the germ-line competency of induced pluripotent stem cells. Nature 463, 1096-1100.

Hanna, J., Cheng, A.W., Saha, K., Kim, J., Lengner, C.J., Soldner, F., Cassady, J.P., Muffat, J., Carey, B.W., and Jaenisch, R. (2010). Human embryonic stem cells with biological and epigenetic characteristics similar to those of mouse ESCs. Proc Natl Acad Sci U S A 107, 9222-9227.

Hanna, J., Markoulaki, S., Schorderet, P., Carey, B.W., Beard, C., Wernig, M., Creyghton, M.P., Steine, E.J., Cassady, J.P., Foreman, R., et al. (2008). Direct reprogramming of terminally differentiated mature B lymphocytes to pluripotency. Cell 133, 250-264.

Hanna, J., Saha, K., Pando, B., van Zon, J., Lengner, C.J., Creyghton, M.P., van Oudenaarden, A., and Jaenisch, R. (2009). Direct cell reprogramming is a stochastic process amenable to acceleration. Nature 462, 595-601.

Hanna, J., Wernig, M., Markoulaki, S., Sun, C.W., Meissner, A., Cassady, J.P., Beard, C., Brambrink, T., Wu, L.C., Townes, T.M., et al. (2007). Treatment of sickle cell anemia mouse model with
iPS cells generated from autologous skin. Science 318, 1920-1923.

Hansis, C., Barreto, G., Maltry, N., and Niehrs, C. (2004). Nuclear reprogramming of human somatic cells by xenopus egg extract requires BRG1. Curr Biol 14, 1475-1480.

Harris, H. (1965). Behaviour of differentiated nuclei in heterokaryons of animal cells from different species. Nature 206, 583-588.

Harris, H., Watkins, J.F., Ford, C.E., and Schoefl, G.I. (1966). Artificial heterokaryons of animal cells from different species. J Cell Sci 1, $1-30$.

Heng, J.C., Feng, B., Han, J., Jiang, J., Kraus, P., Ng, J.H., Orlov, Y.L., Huss, M., Yang, L., Lufkin, T., et al. (2010). The nuclear receptor $\mathrm{Nr} 5 \mathrm{a} 2$ can replace Oct4 in the reprogramming of murine somatic cells to pluripotent cells. Cell Stem Cell 6, 167-174.

Hochedlinger, K., and Plath, K. (2009). Epigenetic reprogramming and induced pluripotency. Development 136, 509-523.

Hong, H., Takahashi, K., Ichisaka, T., Aoi, T., Kanagawa, O., Nakagawa, M., Okita, K., and Yamanaka, S. (2009). Suppression of induced pluripotent stem cell generation by the p53-p21 pathway. Nature 460, 1132-1135.

Huangfu, D., Maehr, R., Guo, W., Eijkelenboom, A., Snitow, M., Chen, A.E., and Melton, D.A. (2008a). Induction of pluripotent stem cells by defined factors is greatly improved by small-molecule compounds. Nat Biotechnol 26, 795-797.

Huangfu, D., Osafune, K., Maehr, R., Guo, W., Eijkelenboom, A., Chen, S., Muhlestein, W., and Melton, D.A. (2008b). Induction of pluripotent stem cells from primary human fibroblasts with only Oct4 and Sox2. Nat Biotechnol 26, 1269-1275.

Hussein, S.M., Batada, N.N., Vuoristo, S., Ching, R.W., Autio, R., Närvä, E., Ng, S., Sourour, M., Hämäläinen, R., Olsson, C., et al. (2011). Copy number variation and selection during reprogramming to pluripotency. Nature 471, 58-62.

Ichida, J.K., Blanchard, J., Lam, K., Son, E.Y., Chung, J.E., Egli, D., Loh, K.M., Carter, A.C., Di Giorgio, F.P., Koszka, K., et al. (2009). A small-molecule inhibitor of tgf-Beta signaling replaces sox2 in reprogramming by inducing nanog. Cell Stem Cell 5, 491-503.

leda, M., Fu, J.D., Delgado-Olguin, P., Vedantham, V., Hayashi, Y., Bruneau, B.G., and Srivastava, D. (2010). Direct reprogramming of fibroblasts into functional cardiomyocytes by defined factors. Cell 142, 375-386.

Inoue, A., and Zhang, Y. (2011). Replication-dependent loss of 5-hydroxymethylcytosine in mouse preimplantation embryos. Science 334, 194.

Itzhaki, I., Maizels, L., Huber, I., Zwi-Dantsis, L., Caspi, O., Winterstern, A., Feldman, O., Gepstein, A., Arbel, G., Hammerman, H., et al. (2011). Modelling the long QT syndrome with induced pluripotent stem cells. Nature 471, 225-229.

Iwasaki, H., Mizuno, S., Arinobu, Y., Ozawa, H., Mori, Y., Shigematsu, H., Takatsu, K., Tenen, D.G., and Akashi, K. (2006). The order of expression of transcription factors directs hierarchical specification of hematopoietic lineages. Genes Dev 20, 3010-3021.

Jang, J., Kang, H.C., Kim, H.S., Kim, J.Y., Huh, Y.J., Kim, D.S., Yoo, J.E., Lee, J.A., Lim, B., Lee, J., et al. (2011). Induced pluripotent stem cell models from $\mathrm{X}$-linked adrenoleukodystrophy patients. Ann Neurol 70, 402-409.

Jiang, J., Chan, Y.S., Loh, Y.H., Cai, J., Tong, G.Q., Lim, C.A., Robson, P., Zhong, S., and Ng, H.H. (2008). A core Klf circuitry 
regulates self-renewal of embryonic stem cells. Nat Cell Biol 10, 353-360.

Judson, R.L., Babiarz, J.E., Venere, M., and Blelloch, R. (2009). Embryonic stem cell-specific microRNAs promote induced pluripotency. Nat Biotechnol 27, 459-461.

Jullien, J., Astrand, C., Halley-Stott, R.P., Garrett, N., and Gurdon, J.B. (2010). Characterization of somatic cell nuclear reprogramming by oocytes in which a linker histone is required for pluripotency gene reactivation. Proc Natl Acad Sci U S A 107, 5483-5488.

Kajimura, S., Seale, P., Kubota, K., Lunsford, E., Frangioni, J.V., Gygi, S.P., and Spiegelman, B.M. (2009). Initiation of myoblast to brown fat switch by a PRDM16-C/EBP-beta transcriptional complex. Nature 460, 1154-1158.

Kawamura, T., Suzuki, J., Wang, Y.V., Menendez, S., Morera, L.B., Raya, A., Wahl, G.M., and Izpisúa Belmonte, J.C. (2009). Linking the p53 tumour suppressor pathway to somatic cell reprogramming. Nature 460, 1140-1144.

Kim, D., Kim, C.H., Moon, J.I., Chung, Y.G., Chang, M.Y., Han, B.S., Ko, S., Yang, E., Cha, K.Y., Lanza, R., et al. (2009a). Generation of human induced pluripotent stem cells by direct delivery of reprogramming proteins. Cell Stem Cell 4, 472-476.

Kim, J., Chu, J., Shen, X., Wang, J., and Orkin, S.H. (2008). An extended transcriptional network for pluripotency of embryonic stem cells. Cell 132, 1049-1061.

Kim, J.B., Greber, B., Araúzo-Bravo, M.J., Meyer, J., Park, K.I., Zaehres, H., and Schöler, H.R. (2009b). Direct reprogramming of human neural stem cells by OCT4. Nature 461, 649-653.

Kim, J.B., Sebastiano, V., Wu, G., Araúzo-Bravo, M.J., Sasse, P., Gentile, L., Ko, K., Ruau, D., Ehrich, M., van den Boom, D., et al. (2009c). Oct4-induced pluripotency in adult neural stem cells. Cell 136, 411-419.

Kim, K., Doi, A., Wen, B., Ng, K., Zhao, R., Cahan, P., Kim, J., Aryee, M.J., Ji, H., Ehrlich, L.I., et al. (2010). Epigenetic memory in induced pluripotent stem cells. Nature 467, 285-290.

King, T.J., and Briggs, R. (1955). Changes in the Nuclei of Differentiating Gastrula Cells, as Demonstrated by Nuclear Transplantation. Proc Natl Acad Sci U S A 41, 321-325.

Klein, G. (1983). Specific chromosomal translocations and the genesis of B-cell-derived tumors in mice and men. Cell 32, 311-315.

Kopp, J.L., Ormsbee, B.D., Desler, M., and Rizzino, A. (2008). Small increases in the level of Sox2 trigger the differentiation of mouse embryonic stem cells. Stem Cells 26, 903-911.

Kuijk, E.W., van Tol, L.T., Van de Velde, H., Wubbolts, R., Welling, M., Geijsen, N., and Roelen, B.A. (2012). The roles of FGF and MAP kinase signaling in the segregation of the epiblast and hypoblast cell lineages in bovine and human embryos. Development 139, 871-882.

Kulessa, H., Frampton, J., and Graf, T. (1995). GATA-1 reprograms avian myelomonocytic cell lines into eosinophils, thromboblasts, and erythroblasts. Genes Dev 9, 1250-1262.

Laiosa, C.V., Stadtfeld, M., Xie, H., de Andres-Aguayo, L., and Graf, $\mathrm{T}$. (2006). Reprogramming of committed $\mathrm{T}$ cell progenitors to macrophages and dendritic cells by C/EBP alpha and PU.1 transcription factors. Immunity $25,731-744$.

Laskey, R.A., and Gurdon, J.B. (1970). Genetic content of adult somatic cells tested by nuclear transplantation from cultured cells.
Nature 228, 1332-1334.

Lee, G., Papapetrou, E.P., Kim, H., Chambers, S.M., Tomishima, M.J., Fasano, C.A., Ganat, Y.M., Menon, J., Shimizu, F., Viale, A., et al. (2009). Modelling pathogenesis and treatment of familial dysautonomia using patient-specific iPSCs. Nature 461, 402-406.

Lefort, N., Feyeux, M., Bas, C., Féraud, O., Bennaceur-Griscelli, A., Tachdjian, G., Peschanski, M., and Perrier, A.L. (2008). Human embryonic stem cells reveal recurrent genomic instability at 20q11.21. Nat Biotechnol 26, 1364-1366.

Lengner, C.J., Gimelbrant, A.A., Erwin, J.A., Cheng, A.W., Guenther, M.G., Welstead, G.G., Alagappan, R., Frampton, G.M., Xu, P., Muffat, J., et al. (2010). Derivation of pre-X inactivation human embryonic stem cells under physiological oxygen concentrations. Cell 141, 872-883.

Li, H., Collado, M., Villasante, A., Strati, K., Ortega, S., Cañamero, M., Blasco, M.A., and Serrano, M. (2009a). The Ink4/Arf locus is a barrier for iPS cell reprogramming. Nature 460, 1136-1139.

Li, R., Liang, J., Ni, S., Zhou, T., Qing, X., Li, H., He, W., Chen, J., Li, F., Zhuang, Q., et al. (2010). A mesenchymal-to-epithelial transition initiates and is required for the nuclear reprogramming of mouse fibroblasts. Cell Stem Cell 7, 51-63.

Li, W., Wei, W., Zhu, S., Zhu, J., Shi, Y., Lin, T., Hao, E., Hayek, A., Deng, H., and Ding, S. (2009b). Generation of rat and human induced pluripotent stem cells by combining genetic reprogramming and chemical inhibitors. Cell Stem Cell 4, 16-19.

Liao, B., Bao, X., Liu, L., Feng, S., Zovoilis, A., Liu, W., Xue, Y., Cai, J., Guo, X., Qin, B., et al. (2011). MicroRNA cluster 302-367 enhances somatic cell reprogramming by accelerating a mesenchymal-to-epithelial transition. J Biol Chem 286, 17359-17364.

Liao, J., Cui, C., Chen, S., Ren, J., Chen, J., Gao, Y., Li, H., Jia, N., Cheng, L., Xiao, H., et al. (2009). Generation of induced pluripotent stem cell lines from adult rat cells. Cell Stem Cell 4, 11-15.

Lister, R., Pelizzola, M., Kida, Y.S., Hawkins, R.D., Nery, J.R., Hon, G., Antosiewicz-Bourget, J., O'Malley, R., Castanon, R., Klugman, S., et al. (2011). Hotspots of aberrant epigenomic reprogramming in human induced pluripotent stem cells. Nature 471, 68-73.

Liu, H., Ye, Z., Kim, Y., Sharkis, S., and Jang, Y.Y. (2010). Generation of endoderm-derived human induced pluripotent stem cells from primary hepatocytes. Hepatology 51, 1810-1819.

Liu, H., Zhu, F., Yong, J., Zhang, P., Hou, P., Li, H., Jiang, W., Cai, J., Liu, M., Cui, K., et al. (2008). Generation of induced pluripotent stem cells from adult rhesus monkey fibroblasts. Cell Stem Cell 3, 587-590.

Loewer, S., Cabili, M.N., Guttman, M., Loh, Y.H., Thomas, K., Park, I.H., Garber, M., Curran, M., Onder, T., Agarwal, S., et al. (2010). Large intergenic non-coding RNA-RoR modulates reprogramming of human induced pluripotent stem cells. Nat Genet 42, 1113-1117.

Loh, Y.H., Agarwal, S., Park, I.H., Urbach, A., Huo, H., Heffner, G.C., Kim, K., Miller, J.D., Ng, K., and Daley, G.Q. (2009). Generation of induced pluripotent stem cells from human blood. Blood 113, 5476-5479.

Loh, Y.H., Wu, Q., Chew, J.L., Vega, V.B., Zhang, W., Chen, X., Bourque, G., George, J., Leong, B., Liu, J., et al. (2006). The Oct4 and Nanog transcription network regulates pluripotency in mouse embryonic stem cells. Nat Genet 38, 431-440.

Maekawa, M., Yamaguchi, K., Nakamura, T., Shibukawa, R., Ko- 
danaka, I., Ichisaka, T., Kawamura, Y., Mochizuki, H., Goshima, N., and Yamanaka, S. (2011). Direct reprogramming of somatic cells is promoted by maternal transcription factor Glis1. Nature 474, 225-229.

Maherali, N., Sridharan, R., Xie, W., Utikal, J., Eminli, S., Arnold, K., Stadtfeld, M., Yachechko, R., Tchieu, J., Jaenisch, R., et al. (2007). Directly reprogrammed fibroblasts show global epigenetic remodeling and widespread tissue contribution. Cell Stem Cell 1, 55-70.

Maki, N., Suetsugu-Maki, R., Sano, S., Nakamura, K., Nishimura, O., Tarui, H., Del Rio-Tsonis, K., Ohsumi, K., Agata, K., and Tsonis, P.A. (2010). Oocyte-type linker histone B4 is required for transdifferentiation of somatic cells in vivo. FASEB J 24, 3462-3467.

Marión, R.M., Strati, K., Li, H., Murga, M., Blanco, R., Ortega, S., Fernandez-Capetillo, O., Serrano, M., and Blasco, M.A. (2009). A p53-mediated DNA damage response limits reprogramming to ensure iPS cell genomic integrity. Nature 460, 1149-1153.

Masui, S., Nakatake, Y., Toyooka, Y., Shimosato, D., Yagi, R., Takahashi, K., Okochi, H., Okuda, A., Matoba, R., Sharov, A.A., et al. (2007). Pluripotency governed by Sox2 via regulation of Oct3/4 expression in mouse embryonic stem cells. Nat Cell Biol 9, 625-635.

Mayshar, Y., Ben-David, U., Lavon, N., Biancotti, J.C., Yakir, B., Clark, A.T., Plath, K., Lowry, W.E., and Benvenisty, N. (2010). Identification and classification of chromosomal aberrations in human induced pluripotent stem cells. Cell Stem Cell 7, 521-531.

McGrath, J., and Solter, D. (1983). Nuclear transplantation in the mouse embryo by microsurgery and cell fusion. Science 1300-1302.

Mikkelsen, T.S., Hanna, J., Zhang, X., Ku, M., Wernig, M., Schorderet, P., Bernstein, B.E., Jaenisch, R., Lander, E.S., and Meissner, A. (2008). Dissecting direct reprogramming through integrative genomic analysis. Nature 454, 49-55.

Miyoshi, N., Ishii, H., Nagano, H., Haraguchi, N., Dewi, D.L., Kano, Y. Nishikawa, S., Tanemura, M., Mimori, K., Tanaka, F., et al. (2011). Reprogramming of mouse and human cells to pluripotency using mature microRNAs. Cell Stem Cell 8, 633-638.

Moretti, A., Bellin, M., Welling, A., Jung, C.B., Lam, J.T., Bott-Flügel, L., Dorn, T., Goedel, A., Höhnke, C., Hofmann, F., et al. (2010). Patient-specific induced pluripotent stem-cell models for long-QT syndrome. N Engl J Med 363, 1397-1409.

Nagamatsu, G., Kosaka, T., Kawasumi, M., Kinoshita, T., Takubo, K., Akiyama, H., Sudo, T., Kobayashi, T., Oya, M., and Suda, T. (2011). A germ cell-specific gene, Prmt5, works in somatic cell reprogramming. J Biol Chem 286, 10641-10648.

Nakagawa, M., Koyanagi, M., Tanabe, K., Takahashi, K., Ichisaka, T., Aoi, T., Okita, K., Mochiduki, Y., Takizawa, N., and Yamanaka, S. (2008). Generation of induced pluripotent stem cells without Myc from mouse and human fibroblasts. Nat Biotechnol 26, 101-106.

Nichols, J., Silva, J., Roode, M., and Smith, A. (2009). Suppression of Erk signalling promotes ground state pluripotency in the mouse embryo. Development 136, 3215-3222.

Nichols, J., Zevnik, B., Anastassiadis, K., Niwa, H., Klewe-Nebenius, D., Chambers, I., Schöler, H., and Smith, A. (1998). Formation of pluripotent stem cells in the mammalian embryo depends on the POU transcription factor Oct4. Cell 95, 379-391.

Niwa, H., Miyazaki, J., and Smith, A.G. (2000). Quantitative expres- sion of Oct-3/4 defines differentiation, dedifferentiation or self-renewal of ES cells. Nat Genet 24, 372-376.

Noggle, S., Fung, H.L., Gore, A., Martinez, H., Satriani, K.C., Prosser, R., Oum, K., Paull, D., Druckenmiller, S., Freeby, M., et al. (2011). Human oocytes reprogram somatic cells to a pluripotent state. Nature 478, 70-75.

Nori, S., Okada, Y., Yasuda, A., Tsuji, O., Takahashi, Y., Kobayashi, Y., Fujiyoshi, K., Koike, M., Uchiyama, Y., Ikeda, E., et al. (2011). Grafted human-induced pluripotent stem-cell-derived neurospheres promote motor functional recovery after spinal cord injury in mice. Proc Natl Acad Sci U S A 108, 16825-16830.

Ohi, Y., Qin, H., Hong, C., Blouin, L., Polo, J.M., Guo, T., Qi, Z., Downey, S.L., Manos, P.D., Rossi, D.J., et al. (2011). Incomplete DNA methylation underlies a transcriptional memory of somatic cells in human iPS cells. Nat Cell Biol 13, 541-549.

Okita, K., Ichisaka, T., and Yamanaka, S. (2007). Generation of germline-competent induced pluripotent stem cells. Nature 448, 313-317.

Okita, K., Nakagawa, M., Hyenjong, H., Ichisaka, T., and Yamanaka, S. (2008). Generation of mouse induced pluripotent stem cells without viral vectors. Science 322, 949-953.

Pander, C.H. (1817). Beiträge zur Entwickelungsgeschichte des Hühnchens im Eye (Wurzburg).

Park, I.H., Arora, N., Huo, H., Maherali, N., Ahfeldt, T., Shimamura, A., Lensch, M.W., Cowan, C., Hochedlinger, K., and Daley, G.Q. (2008). Disease-specific induced pluripotent stem cells. Cell 134, 877-886.

Pavlath, G.K., and Blau, H.M. (1986). Expression of muscle genes in heterokaryons depends on gene dosage. J Cell Biol 102, 124-130.

Pereira, C.F., Terranova, R., Ryan, N.K., Santos, J., Morris, K.J., Cui, W., Merkenschlager, M., and Fisher, A.G. (2008). Heterokaryon-based reprogramming of human $B$ lymphocytes for pluripotency requires Oct4 but not Sox2. PLoS Genet 4, e1000170.

Phanstiel, D.H., Brumbaugh, J., Wenger, C.D., Tian, S., Probasco, M.D., Bailey, D.J., Swaney, D.L., Tervo, M.A., Bolin, J.M., Ruotti, V., et al. (2011). Proteomic and phosphoproteomic comparison of human ES and iPS cells. Nat Methods 8, 821-827.

Polo, J.M., Liu, S., Figueroa, M.E., Kulalert, W., Eminli, S., Tan, K.Y., Apostolou, E., Stadtfeld, M., Li, Y., Shioda, T., et al. (2010). Cell type of origin influences the molecular and functional properties of mouse induced pluripotent stem cells. Nat Biotechnol 28, 848-855.

Prasad, S.M., Czepiel, M., Cetinkaya, C., Smigielska, K., Weli, S.C., Lysdahl, H., Gabrielsen, A., Petersen, K., Ehlers, N., Fink, T., et al. (2009). Continuous hypoxic culturing maintains activation of Notch and allows long-term propagation of human embryonic stem cells without spontaneous differentiation. Cell Prolif 42, 63-74.

Rahl, P.B., Lin, C.Y., Seila, A.C., Flynn, R.A., McCuine, S., Burge, C.B., Sharp, P.A., and Young, R.A. (2010). c-Myc regulates transcriptional pause release. Cell 141, 432-445.

Rashid, S.T., Corbineau, S., Hannan, N., Marciniak, S.J., Miranda, E., Alexander, G., Huang-Doran, I., Griffin, J., Ahrlund-Richter, L., Skepper, J., et al. (2010). Modeling inherited metabolic disorders of the liver using human induced pluripotent stem cells. J Clin Invest $120,3127-3136$.

Raya, A., Rodríguez-Pizà, I., Guenechea, G., Vassena, R., Navarro, 
S., Barrero, M.J., Consiglio, A., Castellà, M., Río, P., Sleep, E., et al. (2009). Disease-corrected haematopoietic progenitors from Fanconi anaemia induced pluripotent stem cells. Nature 460, 53-59.

Redmer, T., Diecke, S., Grigoryan, T., Quiroga-Negreira, A., Birchmeier, W., and Besser, D. (2011). E-cadherin is crucial for embryonic stem cell pluripotency and can replace OCT4 during somatic cell reprogramming. EMBO Rep 12, 720-726.

Rodda, D.J., Chew, J.L., Lim, L.H., Loh, Y.H., Wang, B., Ng, H.H., and Robson, P. (2005). Transcriptional regulation of nanog by OCT4 and SOX2. J Biol Chem 280, 24731-24737.

Roode, M., Blair, K., Snell, P., Elder, K., Marchant, S., Smith, A., and Nichols, J. (2012). Human hypoblast formation is not dependent on FGF signalling. Dev Biol 361, 358-363.

Roux, W. (1888). Beitrage zur Entwicklungsmechanik des Embryo. Virchows Arch Pathol Anat Physiol Klin Med 144, 113-153.

Rowland, B.D., Bernards, R., and Peeper, D.S. (2005). The KLF4 tumour suppressor is a transcriptional repressor of p53 that acts as a context-dependent oncogene. Nat Cell Biol 7, 1074-1082.

Samavarchi-Tehrani, P., Golipour, A., David, L., Sung, H.K., Beyer, T.A., Datti, A., Woltjen, K., Nagy, A., and Wrana, J.L. (2010). Functional genomics reveals a BMP-driven mesenchymal-to-epithelial transition in the initiation of somatic cell reprogramming. Cell Stem Cell 7, 64-77.

Shi, Y., Do, J.T., Desponts, C., Hahm, H.S., Schöler, H.R., and Ding, S. (2008). A combined chemical and genetic approach for the generation of induced pluripotent stem cells. Cell Stem Cell 2, 525-528.

Shi, Y., Kirwan, P., Smith, J., Maclean, G., Orkin, S.H., and Livesey, F.J. (2012). A human stem cell model of early Alzheimer's disease pathology in Down Syndrome. Sci Transl Med 4, 124 ra29.

Silva, J., Chambers, I., Pollard, S., and Smith, A. (2006). Nanog promotes transfer of pluripotency after cell fusion. Nature 441, 997-1001.

Silva, J., Nichols, J., Theunissen, T.W., Guo, G., van Oosten, A.L., Barrandon, O., Wray, J., Yamanaka, S., Chambers, I., and Smith, A. (2009). Nanog is the gateway to the pluripotent ground state. Cell 138, 722-737.

Sommer, C.A., Stadtfeld, M., Murphy, G.J., Hochedlinger, K., Kotton, D.N., and Mostoslavsky, G. (2009). Induced pluripotent stem cell generation using a single lentiviral stem cell cassette. Stem Cells 27, 543-549.

Spemann, H. (1928). Die Entwicklung seitlicher und dorso-ventraler Keimhalften bei verzogerter Kernversogung. Z Wiss Zool 132, 105-134.

Spits, C., Mateizel, I., Geens, M., Mertzanidou, A., Staessen, C., Vandeskelde, Y., Van der Elst, J., Liebaers, I., and Sermon, K. (2008). Recurrent chromosomal abnormalities in human embryonic stem cells. Nat Biotechnol 26, 1361-1363.

Sridharan, R., Tchieu, J., Mason, M.J., Yachechko, R., Kuoy, E., Horvath, S., Zhou, Q., and Plath, K. (2009). Role of the murine reprogramming factors in the induction of pluripotency. Cell 136, 364-377.

Stadtfeld, M., Apostolou, E., Akutsu, H., Fukuda, A., Follett, P., Natesan, S., Kono, T., Shioda, T., and Hochedlinger, K. (2010). Aberrant silencing of imprinted genes on chromosome 12qF1 in mouse induced pluripotent stem cells. Nature 465, 175-181.
Stadtfeld, M., Nagaya, M., Utikal, J., Weir, G., and Hochedlinger, K. (2008). Induced pluripotent stem cells generated without viral integration. Science 322, 945-949.

Stojkovic, M., Stojkovic, P., Leary, C., Hall, V.J., Armstrong, L., Herbert, M., Nesbitt, M., Lako, M., and Murdoch, A. (2005). Derivation of a human blastocyst after heterologous nuclear transfer to donated oocytes. Reprod Biomed Online 11, 226-231.

Subramanyam, D., Lamouille, S., Judson, R.L., Liu, J.Y., Bucay, N., Derynck, R., and Blelloch, R. (2011). Multiple targets of miR-302 and miR-372 promote reprogramming of human fibroblasts to induced pluripotent stem cells. Nat Biotechnol 29, 443-448.

Szabo, E., Rampalli, S., Risueño, R.M., Schnerch, A., Mitchell, R., Fiebig-Comyn, A., Levadoux-Martin, M., and Bhatia, M. (2010). Direct conversion of human fibroblasts to multilineage blood progenitors. Nature 468, 521-526.

Tada, M., Takahama, Y., Abe, K., Nakatsuji, N., and Tada, T. (2001). Nuclear reprogramming of somatic cells by in vitro hybridization with ES cells. Curr Biol 11, 1553-1558.

Takahashi, K., Tanabe, K., Ohnuki, M., Narita, M., Ichisaka, T., Tomoda, K., and Yamanaka, S. (2007). Induction of pluripotent stem cells from adult human fibroblasts by defined factors. Cell 131, 861-872.

Takahashi, K., and Yamanaka, S. (2006). Induction of pluripotent stem cells from mouse embryonic and adult fibroblast cultures by defined factors. Cell 126, 663-676.

Taranger, C.K., Noer, A., Sørensen, A.L., Håkelien, A.M., Boquest, A.C., and Collas, P. (2005). Induction of dedifferentiation, genomewide transcriptional programming, and epigenetic reprogramming by extracts of carcinoma and embryonic stem cells. Mol Biol Cell 16, 5719-5735.

Teranishi, T., Tanaka, M., Kimoto, S., Ono, Y., Miyakoshi, K., Kono, T., and Yoshimura, Y. (2004). Rapid replacement of somatic linker histones with the oocyte-specific linker histone $\mathrm{H} 1$ foo in nuclear transfer. Dev Biol 266, 76-86.

Tesar, P.J., Chenoweth, J.G., Brook, F.A., Davies, T.J., Evans, E.P., Mack, D.L., Gardner, R.L., and McKay, R.D. (2007). New cell lines from mouse epiblast share defining features with human embryonic stem cells. Nature 448, 196-199.

Thomson, J.A., Itskovitz-Eldor, J., Shapiro, S.S., Waknitz, M.A., Swiergiel, J.J., Marshall, V.S., and Jones, J.M. (1998). Embryonic stem cell lines derived from human blastocysts. Science 282 , 1145-1147.

Thorel, F., Népote, V., Avril, I., Kohno, K., Desgraz, R., Chera, S., and Herrera, P.L. (2010). Conversion of adult pancreatic alpha-cells to beta-cells after extreme beta-cell loss. Nature 464 , 1149-1154.

Tomioka, M., Nishimoto, M., Miyagi, S., Katayanagi, T., Fukui, N., Niwa, H., Muramatsu, M., and Okuda, A. (2002). Identification of Sox-2 regulatory region which is under the control of Oct-3/4-Sox-2 complex. Nucleic Acids Res 30, 3202-3213.

Tontonoz, P., Hu, E., and Spiegelman, B.M. (1994). Stimulation of adipogenesis in fibroblasts by PPAR gamma 2, a lipid-activated transcription factor. Cell 79, 1147-1156.

Tsai, S.Y., Clavel, C., Kim, S., Ang, Y.S., Grisanti, L., Lee, D.F., Kelley, K., and Rendl, M. (2010). Oct4 and klf4 reprogram dermal papilla cells into induced pluripotent stem cells. Stem Cells 28 , 221-228. 
Tsonis, P.A., and Del Rio-Tsonis, K. (2004). Lens and retina regeneration: transdifferentiation, stem cells and clinical applications. Exp Eye Res 78, 161-172.

Urbach, A., Bar-Nur, O., Daley, G.Q., and Benvenisty, N. (2010). Differential modeling of fragile $X$ syndrome by human embryonic stem cells and induced pluripotent stem cells. Cell Stem Cell 6, 407-411.

Utikal, J., Polo, J.M., Stadtfeld, M., Maherali, N., Kulalert, W., Walsh, R.M., Khalil, A., Rheinwald, J.G., and Hochedlinger, K. (2009). Immortalization eliminates a roadblock during cellular reprogramming into iPS cells. Nature 460, 1145-1148.

Vierbuchen, T., Ostermeier, A., Pang, Z.P., Kokubu, Y., Südhof, T.C., and Wernig, M. (2010). Direct conversion of fibroblasts to functional neurons by defined factors. Nature 463, 1035-1041.

von Baer, K.E. (1828). Über Entwickelungsgeschichte der Thier. Beobachtung und Reflexion (Königsberg, Bei den Gebrüdern Bornträger).

Wang, T., Chen, K., Zeng, X., Yang, J., Wu, Y., Shi, X., Qin, B., Zeng, L., Esteban, M.A., Pan, G., et al. (2011a). The histone demethylases $\mathrm{Jhdm} 1 \mathrm{a} / 1 \mathrm{~b}$ enhance somatic cell reprogramming in a vitamin-C-dependent manner. Cell Stem Cell 9, 575-587.

Wang, W., Yang, J., Liu, H., Lu, D., Chen, X., Zenonos, Z., Campos, L.S., Rad, R., Guo, G., Zhang, S., et al. (2011b). Rapid and efficient reprogramming of somatic cells to induced pluripotent stem cells by retinoic acid receptor gamma and liver receptor homolog 1. Proc Natl Acad Sci U S A 108, 18283-18288.

Warren, L., Manos, P.D., Ahfeldt, T., Loh, Y.H., Li, H., Lau, F., Ebina, W., Mandal, P.K., Smith, Z.D., Meissner, A., et al. (2010). Highly efficient reprogramming to pluripotency and directed differentiation of human cells with synthetic modified mRNA. Cell Stem Cell 7, 618-630.

Weintraub, H., Tapscott, S.J., Davis, R.L., Thayer, M.J., Adam, M.A., Lassar, A.B., and Miller, A.D. (1989). Activation of muscle-specific genes in pigment, nerve, fat, liver, and fibroblast cell lines by forced expression of MyoD. Proc Natl Acad Sci U S A 86, 5434-5438.

Willadsen, S.M. (1986). Nuclear transplantation in sheep embryos. Nature 320, 63-65.

Wilmut, I., Schnieke, A.E., McWhir, J., Kind, A.J., and Campbell, K.H. (1997). Viable offspring derived from fetal and adult mammalian cells. Nature 385, 810-813.

Woltjen, K., Michael, I.P., Mohseni, P., Desai, R., Mileikovsky, M., Hämäläinen, R., Cowling, R., Wang, W., Liu, P., Gertsenstein, M., et al. (2009). piggyBac transposition reprograms fibroblasts to induced pluripotent stem cells. Nature 458, 766-770.
$\mathrm{Wu}, \mathrm{H}$., and Zhang, Y. (2011). Mechanisms and functions of Tet protein-mediated 5-methylcytosine oxidation. Genes Dev 25, 2436-2452.

Xie, H., Ye, M., Feng, R., and Graf, T. (2004). Stepwise reprogramming of B cells into macrophages. Cell 117, 663-676.

Ying, Q.L., Nichols, J., Evans, E.P., and Smith, A.G. (2002). Changing potency by spontaneous fusion. Nature 416, 545-548.

Ying, Q.L., Wray, J., Nichols, J., Batlle-Morera, L., Doble, B., Woodgett, J., Cohen, P., and Smith, A. (2008). The ground state of embryonic stem cell self-renewal. Nature 453, 519-523.

Yoshida, Y., Takahashi, K., Okita, K., Ichisaka, T., and Yamanaka, S. (2009). Hypoxia enhances the generation of induced pluripotent stem cells. Cell Stem Cell 5, 237-241.

Yu, J., Hu, K., Smuga-Otto, K., Tian, S., and Stewart, R. Slukvin, II, and Thomson, J.A. (2009). Human induced pluripotent stem cells free of vector and transgene sequences. Science 324, 797-801.

Yu, J., Vodyanik, M.A., Smuga-Otto, K., Antosiewicz-Bourget, J., Frane, J.L., Tian, S., Nie, J., Jonsdottir, G.A., Ruotti, V., Stewart, $\mathrm{R}$., et al. (2007). Induced pluripotent stem cell lines derived from human somatic cells. Science (New York, NY 318, 1917-1920.

Yusa, K., Rad, R., Takeda, J., and Bradley, A. (2009). Generation of transgene-free induced pluripotent mouse stem cells by the piggyBac transposon. Nat Methods 6, 363-369.

Yusa, K., Rashid, S.T., Strick-Marchand, H., Varela, I., Liu, P.Q., Paschon, D.E., Miranda, E., Ordóñez, A., Hannan, N.R., Rouhani, F.J., et al. (2011). Targeted gene correction of $\alpha 1$-antitrypsin deficiency in induced pluripotent stem cells. Nature 478, 391-394.

Zhang, J., Lian, Q., Zhu, G., Zhou, F., Sui, L., Tan, C., Mutalif, R.A., Navasankari, R., Zhang, Y., Tse, H.F., et al. (2011). A human iPSC model of Hutchinson Gilford Progeria reveals vascular smooth muscle and mesenchymal stem cell defects. Cell Stem Cell 8, 31-45.

Zhao, T., Zhang, Z.N., Rong, Z., and Xu, Y. (2011). Immunogenicity of induced pluripotent stem cells. Nature 474, 212-215.

Zhao, Y., Yin, X., Qin, H., Zhu, F., Liu, H., Yang, W., Zhang, Q., Xiang, C., Hou, P., Song, Z., et al. (2008). Two supporting factors greatly improve the efficiency of human iPSC generation. Cell Stem Cell 3, 475-479.

Zhou, H., Wu, S., Joo, J.Y., Zhu, S., Han, D.W., Lin, T., Trauger, S., Bien, G., Yao, S., Zhu, Y., et al. (2009). Generation of induced pluripotent stem cells using recombinant proteins. Cell Stem Cell 4, 381-384.

Zhou, Q., Brown, J., Kanarek, A., Rajagopal, J., and Melton, D.A. (2008). In vivo reprogramming of adult pancreatic exocrine cells to beta-cells. Nature 455, 627-632. 